\title{
Peningkatan Hasil Belajar Biologi Konsep Protozoa dengan Pendekatan Inkuiri Pada Siswa Kelas X MIA4 MAN 2 Padangsidimpuan
}

Raisah BR Surbakti

Dosen FTIK IAIN Padangsidimpuan Sumatera Utara

\begin{abstract}
ABSTRAK
Tujuan penelitian ini untuk mengetahui penerapan pendekatan inkuiri dalam pembelajaran biologi pada konsep protozoauntuk meningkatkan hasil belajar siswa kelas XMIA 4 MAN 2 Padangsidimpuan. Rancangan penelitian tindakan kelas ini dilakukan dalam dua siklus dan setiap siklus terdiri dari empat tahap yaitu (1) perencanaan (2) Pelaksanaan (3) observasi (4) refleksi. Pengumpulan data melalui teknik pemberian tes, wawancara, observasi dan pencatatan lapangan. Analisis data dilakukan melalui reduksi, penyajian dan penarikan kesimpulan. Subjek penelitian ini adalah siswa kelas XMIA 4 MAN 2 Padangsidimpuan yang berjumlah 23 orang siswa. Hasil penelitian diperoleh data awal siswa yang kategori tuntas 0 orang atau persentase ketuntasan klasikal $0 \%$. Pada siklus 1 banyak siswa yang tuntas pada indikator 1 ada 12 siswa dan indikator 2 siswa tuntas 10 siswa, persentase ketuntasan klasikal 48,3\%. Sedangkan Siklus II banyaknya siswa yang tuntas pada indikator 1 adalah 22 siswa dan indikator 2 sebanyak 21 siswa, persentase ketuntasan klasikal $94 \%$. Hasil penelitian tersebut menunjukkan bahwa pendekatan inkuiri dapat meningkatkan hasil belajar. Siswa yang aktif saat pembelajaran konsep protozoa dengan pembelajaran metode inkuiri siklus I sebesar 36,83\%, Pada siklus II keaktifan siswa sebesar 89,8\%, Pada siklus II keaktifan siswa sebesar 89,9\%. Sikuls II sudah mencapai efektif dari segi proses yaitu pembelajaran dikatakan efektif, karena aktivitas siswa telah mencapai $85 \%$ siswa terlibat secara aktif.
\end{abstract}

Kata Kunci: Hasil Belajar, Pendekatan Inkuiri, Prozoa 


\section{PENDAHULUAN}

Pembelajaran menunjuk pada proses pengajaran yang berpusat pada tujuan yang dalam banyak hal dapat direncanakan sebelumnya. Pembelajaran adalah upaya pendidik untuk membantu peserta didik melakukan kegiatan belajar. Tujuan pembelajaran adalah terwujudnya efisiensi dan efektifitas kegiatan belajar yang dilakukan peserta didik. Pihak-pihak yang terlibat dalam pembelajaran adalah pendidik dan peserta didik yang berinteraksi edukatif antara satu dengan yang lainnya

Pembelajaran IPA berbeda dengan pengajaran IPA. Dalam pengajaran IPA, guru lebih banyak menyampaikan ide atau gagasan sehingga siswa bertindak pasif, dan guru lebih aktif. Sementara dalam pembelajaran IPA siswa harus aktif dan lebih dominan dalam kegiatan belajar mengajar, sedangkan guru lebih berperan sebagai fasilitator dan dinamisator.

Aktivitas belajar adalah kemampuan yang dimiliki siswa setelah menerima proses pembelajaran. Individu yang mendapat pembelajaran akan memperoleh hasil dari apa yang telah dipelajari selama proses pembelajaran itu. Hasi belajar bukan hanya dalam pengetahuan, tetapi juga membentuk kecakapan, kebiasaan, pengertian, penguasaan, dan penghargaan dalam diri seseorang yang belajar.

Penilaian adalah proses memberikan atau menentukan nilai kepada objek tertentu berdasarkan suatu kriteria tertentu Untuk dapat menentukan suatu nilai atau harga suatu objek diperlukan adanya ukuran atau kriteria. Hasil belajar pada dasarnya merupakan akibat dari suatu proses belajar

Secara umum pengertian hasil belajar adalah perubahan perilaku dan kemampuan secara keseluruhan yang dimiliki oleh siswa setelah belajar, yang wujudnya berupa kemampuan kognitif, afektif, dan psikomotor yang disebabkan oleh pengalaman dan bukan hanya salah satu aspek potensi saja.Setelah suatu proses belajar berakhir, maka siswa memperoleh suatu hasil belajar. Hasil belajar mempunyai peranan penting dalam proses pembelajaran. Hasil belajar digunakan untuk mengetahui sebatas mana siswa dapat memahami serta mengerti materi tersebut

Hasil belajar menjadi sebuah pengukuran dari penilaian kegiatan belajar atau proses belajar dinyatakan dalam simbol, huruf maupun kalimat yang menceritakan hasil yang sudah dicapai oleh setiap anak atau siswa pada suatu periode tertentu.Hasil belajar 
juga dapat dilihat melalui kegiatan evaluasi yang bertujuan untuk mendapatkan data pembuktian yang akan menunjukkan tingkat kemampuan siswa dalam mencapai tujuan pembelajaran. Hasil belajar siswa ini dipengaruhi oleh kamampuan siswa dan kualitas pengajaran.Kualitas pengajaran yang dimaksud adalah profesionalitas dan keahlian yang dimiliki oleh guru. Artinya kemampuan dasar guru baik di bidang kognitif (intelektual).

Pembelajaran dikatakan berhasil sesuai dengan harapan dipengaruhi oleh faktorfaktor yang saling berkaitan dan saling menunjang. Faktor yang paling menentukan keberhasilan pembelajaran adalah guru sebagai fasiitator dan motivator, sehingga guru sangat dituntut kemampuannya untuk membuat strategi agar konsep dikuasai siswa dengan baik, untuk itu guru perlu menguasai tentang metode, pendekatan,strategi, model, dan media pengajaran yang dapat di gunakan dalam proses belajar mengajar.

Dari hasil pengamatan proses pembelajaran di siswa kelas XMIA 4 MAN 2 Padangsidimpuan, ternyata belum sepenuhnya melibatkan fisik dan mental siswa, sehingga dalam proses pembelajaran terkesan siswa kurang aktif, proses pembelajaran guru tidak maksimal, masih menggunaan metode ceramah dan jarang sekali guru mensiasati dan memamfaatkan media yang ada pada alam. Sehingga hasil belajar yang di peroleh siswa tidak memenuhi KKM yaitu 85. Hal ini dapat dilihat dari rata-rata ulangan yang telah dilaksanakan di kelas X MIA 4 MAN 2 Padangsidimpuan yaitu 65. Rendahnya hasil belajar ini tidak jauh berbeda dengan data yang diperoleh pada saat pembelajaran sebeumnya.

Berdasarkan hasil observasi diperoleh informasi bahwa rendahnya hasil belajar siswa kelas X MIA 4 tersebut dalam mata pelajaran biologi disebabkan oleh beberapa faktor yaitu: (1) kurangnya partisipasi siswa dalam pembelajaran di kelas. Kesempatankesempatan yang diberikan oleh guru kepada siswa untuk bertanya mengenai materi pelajaran yang belum dimengerti tidak dimanfaatkan dengan baik oleh siswa. (2) Guru mengajar dengan menggunakan metode yang monoton yaitu metode ceramah, sehingga siswa cenderung bosan dalam pembelajaran. (3) keaktifan siswa dalam menjawab, menyelesaikan tugas-tugas masih sangat kurang. Konsep protozoa sebagai konsep esensial untuk memahami keanekaragaman hayati, karena bagian dari keanekaragaman hayati adalah jasat renih dan mahkuk purba kala yaitukingdom protista mirip hewan 
yang disebut protozoa. Dari sisi untuk pemahaman konsep protozoa termasuk proses konsep abstrak karena protozoa adalah makhluk kecil sehingga tidak bisa dilihat tanpa peralatan teknologi yang mutakhir, namun protozoa adalah mahkluk mirip hewan tersebut adalah sangat nyata.

Dengan kondisi seperti itu dipandang perlu diadakan perbaikan pelaksanaan proses pembelajaran untuk meningkatkan hasil belajar siswa, salah satu cara untuk meningkatkan pelaksanaan proses pembelajaran, guru harus mampu memilih dan menggunakan metode yang tepat. Metode yang cocok untuk pemahaman muasi adalah metode inkuiri. Metode inkuiri adalah suatu cara menyampaikan pelajaran yang meletakkan dan mengembangkan cara berfikir ilmiah dimana siswa mengasimilasi suatu konsep atau prinsip, misalnya mengamati, menggolongkan, membuat dugaan, menjelaskan, mengukur, dan membuat kesimpulan dan sebagainya, cara penyajian pelajaran dengan memberi kesempatan kepada peserta didik untuk menemukan informasi dengan atau tanpa bantuan guru ${ }^{1}$.

Metode Inkuiri memungkinkan para peserta didik menemukan sendiri informasiinformasi yang diperlukan untuk mencapai tujuan belajarnya, karena metode inkuiri melibatkan peserta didik dalam proses-proses mental untuk penemua suatu konsep berdasarkan informasi-informasi yang diberikan guru ${ }^{2}$. Sanjaya 'inkuiri merupakan pembelajaran yang menekankan kepada pengembangan aspek kognitif, afektif, dan psikomotor, secara seimbang sehingga pembelajaran akan lebih bermakna ${ }^{3}$.

\footnotetext{
${ }^{1}$ Haury. (1993). Pembelajaran Metode Inkuiri. (Jakarta : Depdikbud. 1993) hlm 10

${ }^{2}$ Mulyani Sumantri dan Johar Permana, Strategi Belajar Mengajar, (Jakarta : Direktorat Jendral Pendidikan Tinggi,.2009) hlm.15

3Rosmiati (2002). Interaksi Dan Motivasi Belajar Mengajar. Rajawali Press. Jakarta
} 


\section{METODELOGI PENELITIAN}

Penelitian yang dilaksanakan adalah penelitian tindakan kelas (PTK). Rangkaian kegiatan dalam Penelitian Tindakan Kelas ini mengacu pada pedoman PTK dari Kemmis dan Robin MC Taggart ${ }^{4}$. PTK sangat erat hubungannya dengan praktek pembelajaran yang dihadapi guru ${ }^{5}$

Tujuan melakukan PTK yaitu untuk meningkatkan dan memperbaiki praktek yang seharusnya dilakukan oleh guru, sehingga guru akan lebih banyak berlatih mengaplikasikan berbagai tindakan alternatif sebagai upaya untuk meningkatkan layanan pembelajaran dari pada perolehan pengetahuan umum dalam bidang pendidikan yang dapat digeneralisasikan.

Penelitian tindakan kelas ini adalah penelitian yang dimaksud untuk memperbaiki pembelajaran. Penelitian tindakan kelas ini direncanakan akan dilaksanakan dalam dua siklus, dimana masing-masing siklus terdiri dari empat tahap, meliputi; 1) tahap perencanaan, 2) tahap pelaksanaan, 3) tahap evalasi/observasi, dan 4) tahap refleksi ${ }^{6}$.

Penelitian ini dilaksanakan di kelas XMIA 4 MAN 2 Padangsidimpuan Sumatera Utara. Waktu penelitian dilaksanakan pada bulan Januari sampai bulan Februari 2019. Sampel penelitian ini adalah siswa yang terdaftar pada tahun pelajaran 2019/2020 sebanyak 23 siswa, terdiri dari 15 siswa perempuan serta 8 siswa laki-laki dan guru biologi kelas X MIA 4 MAN 2 Padangsidimpuan dengan teknik Purposive Sampling yaitu mengambil seluruh murid kelas X MIA 4 yang berjumlah 23 orang.

Jenis data yang diperoleh dalam penelitian ini adalah: Data kualitatif yaitu data yang hasil observasi aktivitas guru dan aktivitas siswa dalam pembelajaran biologi konsep mutasi dengan menggunakan metode inkuiri. Data kuantitatif yaitu data yang di peroleh dari hasil tes akhir siswa. Data observasi siswa, data yang di peroleh dari hasil observasi aktivitas siswa dan tes kemampuan akhir siswa tiap siklus.

\footnotetext{
${ }^{5}$ Ibid, hlm.45

${ }^{6}$ Padmono. Penelitian Tindakan Kelas. (Surakarta: Pelangi Press. 2012) hlm.8
} 
Pengumpulan data dilakukan melalui dua cara, yaitu: Tes untuk mengetahui peningkatan hasil belajar siswa selama pembelajaran biologi konsep konsep protozoa yang di berikan di setiap akhir tindakan (siklus). Hasil kemampuan akhir siswa dapat pula sebagai acuan untuk mengetahui hasil belajar siswa setelah mengikuti pembelajaran biologi konsep protozoa dengan menggunakan metode inkuiri. Observasi dilakukan selama kegiatan pembelajaran siklus 1 dan siklus 2 berlangsung. Pelaksanaan observasi baik pada guru/peneliti dan kepada subyek penelitian dilakukan dengan cara mengisi format observasi yang telah di siapkan oleh peneliti dengan tujuan untuk mengetahui aktifitas siswa pada saat kegiatan pembelajaran berlangsung.

Instrumen yang digunakan dalam penelitian ini adalah: Lembar observasi, Tes hasil belajar, setelah diberikan penerapan metode Inkuiri. Analisis data dalam penelitian ini dilakukan sesudah pengumpulan data.

Adapun tahap-tahap kegiatan analisis data kualitatif adalah: 1) mereduksi data 2) menyajikan data dan 3) verifikasi data / penyimpulan ${ }^{7}$ Indikator keberhasilan penelitian tindakan kelas adalah apabila hasil data yang diperoleh telah menunjukan hasil belajar siswa kelas X MIA 4 MAN 2 Padangsidimpuan selama kegiatan pembelajaran. Hal ini ditandai dengan adanya daya serap individu minimal $85 \%$ dan ketuntasan belajar klasikal minimal $85 \%$ dari jumlah siswa yang ada.

Dari segi proses begitu juga dari segi proses pembelajaran dikatakan efektif bila 85\% siswa telah terlibat secara aktif, baik mental, fisik, mental, maupun sosial, ketentuan ini sesuai dengan kriteria ketuntasan minimal (KKM) yang diberlakukan di MAN 2 Padangsidimpuan.

\footnotetext{
${ }^{7}$ Sugiyono. Metode Penelitian Pendidikan (Pendekatan Kuantitatif, Kualitatif, dan R\&D). (Bandung: Alfabeta.2008) hlm 18
} 


\section{HASIL PENELITIAN DAN PEMBAHASAN}

Kegiatan diawali dengan pertemuan antara peneliti dengan guru biologi yang lainnya untuk membicarakan rencana penelitian di kelas XMIA 4 MAN 2 Padangsidimpuan. Peneliti juga meminta kesediaan teman sejawat, untuk menjadi observer yang tugasnya mengamati kegiatan siswa dan guru pemberi tindakan saat proses pembelajaran berlangsung, disamping sebagai teman berdiskusi. Kemudian peneliti menemui siswa kelas X MIA 4 untuk membicarakan rencana perbaikan pembelajaran sebagai tindak lanjut dari hasil pelaksanaan pembelajaran biologi yang masih tergolong rendah.

Hasil observasi tentang kegiatan guru dimaksud untuk mengetahui tingkat kemampuan guru (peneliti) dalam menyusun dan melaksanakan pembelajaran dengan menggunakan metode inkuiri pada mata pelajaran biologi konsep protozoa di Kelas XMIA 4 MAN 2 Padangsidimpuan

Memperhatikan hasil penelitian yang dilaksanakan siswa di Kelas X MIA 4 MAN 2 Padangsidimpuan yang diambil dari hasil evaluasi baik evaluasi pra penelitian (tes awal) maupun hasil evaluasi pelaksanaan pembelajaran persiklus dapat menunjukkan bahwa peningkatan hasil belajar siswa dapat meningkat secara bertahap dengan menerapkan metode inkuiri yang baik dan benar. Deskripsi hasil pelaksanaan penelitian tersebut akan kita bahas secara bertahap sebagai berikut:

Sebelum melaksanakan proses tindakan penerapan metode diskusi pada mata pelajaran biologi di kelas X MIA 4 MAN 2 Padangsidimpuan pada siklus 1, diadakan tindakan observasi awal dengan memberikan soal tes kepada siswa, di mana nilai yang didapatkan dari hasil observasi awal ternyata daya serap individu masih $50 \%$ baik dari indikator 1 dan indikator 2, jadi masih jauh berada pada level di rata-rata bawah.

Daya serap individu masih berada pada nilai kurang dari $85 \%$ sebagai patokan ketercapaian ketuntasan individu dalam pembelajaran, begitu pula dengan ketuntasan klasikal yang diperoleh yang hanya mencapai 48,3\%. Jika di lihat dari hasil ketuntasan klasikal ini masih jauh dari standar ketuntasan klasikal yang diharapkan yaitu $85 \%$.

Hal tersebut di atas terjadi karena pemberian pembelajaran di setiap proses belajarmengajar hanya menekankan pada pemberian materi semata, sehingga hilanglah rasa beban dan tanggung jawabnya sebagai guru yang bertugas memberikan pembelajaran 
pada siswa. Setiap hari belajar siswa dipenuhi dengan metode cermah dan diskusi. Proses belajar-mengajar sangat monoton, selama kegiatan belajar mengajar hanya di monopoli oleh guru sebagai pentransfer ilmu tanpa memberikan kesempatan kepada siswa untuk mengembangkan daya nalarnya.

Selama ini guru biologi cenderung menguasai proses belajar-mengajar, sehingga siswa pun kurang termotivasi, kurang kreaktif dan cenderung vakum dalarn proses pembelajaran yang akhirnya mempengaruhi tingkat kemampuan siswa dalam menelaah dan mendeskripsikan setiap pokok bahasan yang diberikan. Akibatnya dapat menurunkan kualitas siswa dalam belajar yang berdampak pada minimnya hasil yang diperoleh siswa.

Hasil evaluasi yang didapatkan pada siklus I yang terdapat pada tabel.1

Tabel 1. Perbandingan Penilaian Hasil Belajar Konsep Protozoa Siklus I dan Siklus II.

\begin{tabular}{|c|c|c|c|c|c|c|}
\hline \multirow[t]{3}{*}{ No } & \multirow[t]{3}{*}{ Indikator } & \multicolumn{4}{|c|}{ Siklus } & \multirow[t]{3}{*}{ Keterangan } \\
\hline & & \multicolumn{2}{|r|}{ I } & \multicolumn{2}{|c|}{ II } & \\
\hline & & Jlh & $\%$ & Jlh & $\%$ & \\
\hline 1 & $\begin{array}{lrr}\text { Mengkaji } & & \text { konsep } \\
\text { protozoa } & \text { dari } & \text { bebagai } \\
\text { bentuk } & \text { dari } & \text { alat } \\
\text { geraknya } & & \text { melalui } \\
\text { referensi } & & \end{array}$ & 12 & $52,2 \%$ & 22 & $95,7 \%$ & Meningkat \\
\hline 2 & $\begin{array}{l}\text { Mengobservasiprotozoa } \\
\text { keberadaan dia alam }\end{array}$ & 10 & $44,47 \%$ & 21 & $92,3 \%$ & Meningkat \\
\hline & Rerata & & $48,3 \%$ & & $94 \%$ & \\
\hline
\end{tabular}

Dari tabel di atas menunjukkan peningkatan hasil belajar siswa terhadap konsep konsep protista mirip hewan atau protozoa mata biologi dimana terdapat 12 siswa $(52,2, \%)$ berhasil mendapatkan kategori tuntas individu pada indikator 1 dan masih tersisa 11 orang anak $(47,8 \%)$ berada pada kategori tidak tuntas individu, sementara pada indikator 2 menunjukkan peningkatan hasil belajar siswa terhadap konsep konsep protista mirip mata biologi dimana terdapat 10 siswa $(44,47, \%)$ berhasil mendapatkan 
kategori tuntas individu dan masih tersisa 13 siswa anak $(59, \%)$ berada pada kategori tidak tuntas individu.pada sikulus 1 .

Sementara pada siklus 2 menunjukkan peningkatan hasil belajar siswa terhadap konsep konsep protista mirip hewan atau protozoa mata biologi dimana terdapat 22 siswa $(95,7, \%)$ berhasil mendapatkan kategori tuntas individu dan hanya tersisa 1 orang anak $(4,35 \%)$ berada pada kategori tidak tuntas individu, pada indikator 2 jumlah siswa yang tuntas 21 siswa $(92,3, \%)$ berhasil mendapatkan kategori tuntas individu dan tersisa 2 orang anak $(8,7 \%)$ berada pada kategori tidak tuntas individu .

Secara klasikal ketuntasan konsep telah mencapai 94\%. Menilik dari hasil siklus 1 dan siklus 2 ketuntasan klasikal mengalami peningkatan yaitu dari 48,3 \% menjadi 94\%, namun demikian proses pembelajaran pada siklus I ini belum dikatakan berhasil karena secara klasikal karena harus memperoleh nilai $85 \%$.

Seorang anak yang belum mencapai ketuntasan individu 1 siswa, ini sudah menunjukkan peningkatan prestasi yang berarti, yaitu dari 48,3\% ketuntasan individu pada siklus I menjadi 94\% ketuntasan individu pada siklus 1, anak yang belum mencapai ketuntasan individu 2 siswa, ini sudah menunjukkan peningkatan prestasi yang berarti, yaitu dari 50\% ketuntasan individu pada siklus I menjadi 94\% ketuntasan individu pada siklus 2 dengan demikian siswa belum tuntas perlu mendapatkan bimbingan khusus untuk meningkatkan dan mempertahankan prestasi belajarnya yang sudah didapatkan.

Adapun peningkatan penilaian proses pembelajaran menggunakan metode inkuiri pada mata pelajaran biologi konsep protozoadapat dilihat pada tabel 2 perbandingan penilaian proses pembelajaran menggunakan metode inkuiri pada mata pelajaran biologi konsep protista mirip hewan atau protozoaSiklus I dan Siklus II sebagai berikut: 
Tabel 1 Perbandingan Penilaian Aktivitas Siswa Pembelajaran Konsep Protozoa dengan Menggunakan Metode Inkuiri Siklus I dan Siklus II.

\begin{tabular}{|c|c|c|c|c|c|c|}
\hline \multirow{3}{*}{\begin{tabular}{|l}
$\mathrm{N}$ \\
$\mathrm{O}$ \\
\end{tabular}} & \multirow[t]{3}{*}{ Aspek yang dinilai } & \multicolumn{4}{|c|}{ Siklus } & \multirow{3}{*}{$\begin{array}{l}\text { Kete } \\
\text { Rangan }\end{array}$} \\
\hline & & \multicolumn{2}{|l|}{ I } & \multicolumn{2}{|l|}{ II } & \\
\hline & & Jlh & $\%$ & Jlh & $\%$ & \\
\hline 1 & $\begin{array}{l}\text { Kesiapan Siswa mengikuti } \\
\text { kegiatan belajar menggunakan } \\
\text { metode inkuiri pada mata } \\
\text { pelajaran biologi konsep } \\
\text { protozoa }\end{array}$ & 12 & $52,2 \%$ & 21 & $91,3 \%$ & Meningkat \\
\hline 2 & $\begin{array}{l}\text { Perhatian siswa dalam mengikuti } \\
\text { kegiatan pembelajaran }\end{array}$ & 11 & $47,8 \%$ & 22 & $95,7 \%$ & Meningkat \\
\hline 3 & $\begin{array}{l}\text { Keaktifan siswa dalam } \\
\text { mengembangkan pikirannya } \\
\text { dengan cara membuat data } \\
\text { temuan dari protozoa berkaki } \\
\text { semu, tanpa kaki, berbulu } \\
\text { cambuk, dan berbulu getar. }\end{array}$ & 6 & $26,1 \%$ & 20 & $87 \%$ & Meningkat \\
\hline 4 & \begin{tabular}{l}
\multicolumn{3}{l}{ Kemampuan siswa menggunakan } \\
metode inkuiri pada mata \\
pelajaran biologi konsep \\
protozoadengan lengkap
\end{tabular} & 7 & $30,4 \%$ & 21 & $91 \%$ & Meningkat \\
\hline 5 & $\begin{array}{l}\text { Kemampuan menyajikan hasil } \\
\text { kerja secara individu }\end{array}$ & 8 & $34,8 \%$ & 20 & $87 \%$ & Meningkat \\
\hline 6 & $\begin{array}{l}\text { Aktivitas siswa dalam } \\
\text { menyelesaikan tugas individu }\end{array}$ & 7 & $30,4 \%$ & 20 & $87 \%$ & Meningkat \\
\hline & Rerata & & $36,83 \%$ & & $89,8 \%$ & \\
\hline
\end{tabular}

Berdasarkan Tabel. 2. Siswa yang aktif saat pembelajaran konsep protozoa dengan pembelajaran metode inkuiri siklus I sebesar 36,83\%, Pada siklus II keaktifan siswa sebesar $89,8 \%$, Sikuls I belum mencapai dari segi proses yaitu pembelajaran belum dikatakan efektif, karena aktivitas siswa belum mencapai $85 \%$ siswa terlibat secara aktif.

Pada siklus II keaktifan siswa sebesar $89,9 \%$. Sikuls II sudah mencapai efektif dari segi proses yaitu pembelajaran dikatakan efektif, karena aktivitas siswa telah 
mencapai $85 \%$ siswa terlibat secara aktif. Perbandingan penilaian aktivitas siswa pada pembelajaran biologi konsep protozoadengan menggunakan metode inkuiri terjadi peningkatan secara signifikan, peningkatan siklus I ke siklus II bahwa rata-rata peningkatan dari siklus I ke siklus II yaitu mencapai 52,97\% .

Sedangkan dari sisi refleksi dari masing-masing siklus menunjukkan adanya peningkatan proses aktivitas belajar siswa sebesar $89,8 \%$ siswa aktif. Proses pembelajaran tersebut mencapai indikator keberhasilan proses pembelajaran yang telah ditentukan oleh peneliti.

Berdasarkan uraian di atas dapat ditarik kesimpulan bahwa perubahan tingkah laku yang diperoleh sebagai hasil dari belajar adalah perubahan yang terjadi mencakup seluruh aspek tingkah laku. Perubahan yang diperoleh individu dari hasil belajar adalah meliputi perubahan keseluruhan tingkah laku baik dari keaktivan saat pembelajaran, keberanian berpendapat, ketekunan dan keberanian, serta kerja sama.

Penggunaan metode inkuiri dalam pembelajaran, dapat menyalurkan pesan dan maksud kepada siswa sehingga menurut peneliti hal itu dapat merangsang pikiran, perasaan, serta perhatian siswa sedemikian rupa sehingga proses pembelajaran terjadi, tidak terdapat kekeliruan. Tercipta interaksi dan komunikasi yang santai dan terarah. Hal-hal yang demikianlah membuat siswa menjadi senang sehingga mengikuti penuh proses pembelajaran.

Keunggulan metode inkuiri dalam pembelajaran : (a) membantu peserta didik untuk mengembangkan, kesiapan, serta penguasaan ketrampilan dalam proses kognitif, (b) peserta didik memperoleh pengetahuan secara individual sehingga dapat dimengerti dan mengendap dalam pikirannya, (c) dapat membangkitkan motivasi dan gairah belajar peserta didik untuk belajar lebih giat lagi, (d) memberikan peluang untuk berkembang dan maju sesuai dengan kemampuan dan minat masing-masing, dan (e) memperkuat dan menambah kepercayaan pada diri sendiri dengan proses menemukan sendiri karena pembelajaran berpusat pada peserta didik dengan peran guru yang sangat terbatas.

Selain itu siswa ikut berpartisispasi secara aktif didalam kegiatan belajarnya, sebab metode inkuiri menekankan poad proses pengolahan informasi pada peserta didik. Siswa benar-benar dapat memahami suatu konsep dan temuan-temuan di lingkungan, sebab siswa mengalami sendiri proses untuk mendapatkan konsep atau rumus tersebut. 
Metode ini merangsang sikap ilmiah dan menimbulakan semangat keingintahuan para siswa. Menemukan sendiri siswa merasa sangat puas dengan demikian kepuasa mental sebagai nilai intrinsik siswa terpenuhi.

Namun kelemahan dari metode inkuiri antara lain: (a) siswa harus memiliki kesiapan dan kematangan mental, siswa harus berani dan berkeinginan untuk mengetahui keadaan sekitarnya dengan baik, (b) keadaan kelas kenyataannya gemuk jumlah siswanya, maka metode ini tidak akan mencapai hasil yang memuaskan, (c) guru dan siswa yang sudah sangat terbiasa dengan proses belajar mengajar gaya lama, maka metode inkuiri ini akan mengecewakan, dan (d) ada kritik, bahwa proses dalam metode inkuiri terlalu mementingkan proses pengertian saja, kurang memperhatikan perkembangan sikap dan ketrampilan bagi siswa.

Berdasarkan kajian di atas, maka yang dimaksud dengan metode inkuiri dalam penelitian ini adalah kegiatan pembelajaran yang melibatkan secara maksimal seluruh kemampuan peserta didik dalam proses generalisasi dan menguji hipotesa sehingga mereka dapat menemukan sendiri pengetahuan, sikap, dan ketrampilan sebagai wujud perubahan tingkah laku.

Langkah-langkah dalam metode inkuiri mulai dari mengidentifikasi kebutuhan siswa, mempersiapkan fasilitas yang diperlukan, memberi penguatan kepada peserta didik untuk giat dalam melakukan penemuan, sampai dengan memfasilitasi peserta didik dalam merumuskan prinsip-prinsip dari generalisasi atas hasil temuannya.

Pembelajaran inkuiri ini adalah salah satu cara untuk penelaahan yang bersifat mencari pemecahan masalah dengan cara kritis, analitis, dan ilmiah dengan menggunakan langkah-langkah tertentu menuju suatu kesimpulan yang meyakinkan karena didukung oleh data atau kenyataan. Model inkuiri ini merupakan perluasan dari model discovery learning yang digunakan lebih mendalam artinya pembelajaran ini mengandung proses mental yang lebih tinggi tingkatanya. Misalnya merumuskan problema, merancang eksperimen, melaksanakan eksperimen, mengumpulkan data, menganalis data, membuat kesimpulan, dan sebagainya 


\section{V . KESIMPULAN DAN SARAN}

Dari hasil penelitian yang dilaksanakan, maka dapat disimpulan. Pengunaan pendekatan Inkuiri dalam proses pembelajaran, dapat meningkatkan hasil belajar siswa pada mata pelajaran biologi pada konsep protozoadi Kelas XII MIA 6 MAN 2 Padangsidimpuan . Hal ini dapat ditunjukan dari perolehan peningkatan secara klasikal di siklus I yaitu 48,8\% dan siklus II yaitu 94\%.

Kami mengajak para guru untuk menggunakan hasil penelitian ini dengan baik dan dijadikan motivasi agar mampu melakukan penelitian tindakan kelas yang berbeda. Penerapan pendekatan inkuiri hanyalah satu dari sekian banyak pendekatan pembelajaran yang dapat digunakan. Para guru dapat mencari berbagai media atau strategi pembelajaran yang lain yang unik untuk meningkatkan kompetensi siswa. 


\section{DAFTAR RUJUKAN}

Depdikbud. (1995). Kurikulum Lanjutan Tingkat Atas (SLTA). Dirjen Pendidikan Dasar dan Menengah. Jakarta

Anitah, Sri.( 2009) Teknologi Pembelajaran Surakarta: Yuma Pustaka

Arsyad, A. (2011). Media Pembelajaran Jakarta: Raja Grafindo Persada.

Haury. (1993). Pembelajaran Metode Inkuiri. Jakarta : Depdikbud.

Kasbolah, K. (2011). Penelitian Tindakan Kelas. Malang: Universitas Negeri

Malang.

Padmono. (2012). Penelitian Tindakan Kelas. Surakarta: Pelangi Press.

Rosmiati (2002). Interaksi Dan Motivasi Belajar Mengajar. Rajawali Press. Jakarta

Subyantoro,(2009) Penelitian Tindakan Kelas, (Semarang: CV. Widya Karya.

Sugiyono. (2008). Metode Penelitian Pendidikan (Pendekatan Kuantitatif,

Kualitatif, dan R\&D). Bandung: Alfabeta.

Sanjaya, W.(2009). Strategi Pembelajaran Berorientasi Standar Proses Pendidikan.

Jakarta: Kencana Perdana Media Group.

Sugiyanto.(2008). Model-Model Pembelajaran Inovatif. Surakarta: Panitia Sertifikasi

Guru (PSG) Rayon 13. 